\title{
Die statistischen und genetischen Grundlagen von \\ Körpermessungen am Rind
}

\section{Doctoral Thesis}

Author(s):

Weber, Fritz

Publication date:

1957

Permanent link:

https://doi.org/10.3929/ethz-a-000091923

Rights / license:

In Copyright - Non-Commercial Use Permitted 


\title{
Die statistischen und genetischen Grundlagen von Körpermessungen am Rind
}

\author{
VON DER \\ EIDGENOOSSISCHEN TECHNISCHEN HOCHSCHULE IN ZÜRICH \\ ZUR ERLANGUNG \\ DER WÜRDE EINES DOKTORS \\ DER TECHNISCHEN WISSENSCHAFTEN \\ GENEHMIGTE, \\ PROMOTIONSARBEIT
}

VORGELEGT VON

FRITZ WEBER

von Täuffelen (Kt. Bern)

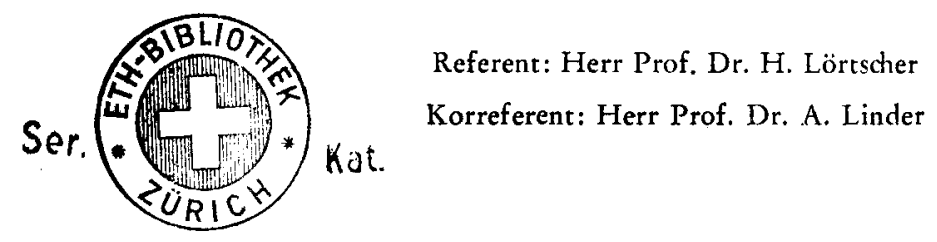

Druck: Felgentreff \& Co., Berlin SW 29 
An und für sich könnte eine entsprechende Gleichung auch für den genetischen Gestaltfaktor aufgestellt werden. Es erscheint aber nicht sinnvoll, Regressionskoeffizienten, die aus genetischen Korrelationen entwickelt worden sind, mit phänotypischen Größen (Wh, $\mathrm{Kbh}, \mathrm{Bt}, \mathrm{Hb}$ und $\mathrm{Bu}$ ) zu verknüpfen. Dem Resultat könnte keine konkrete biologische Bedeutung zugemessen werden. Wir beschränken uns deshalb auf die Berechnung des phänotypischen Gestaltfaktors. Die Heritabilität dieses Faktors beträgt:

$$
\begin{aligned}
\text { phänotypischer Gestaltfaktor: } & h^{2}=0,516 \pm 0,156 . \\
\text { Vergleiche dazu: } & h^{2} \mathrm{Wh}: 0,632 \pm 0,134 \\
& \mathrm{~h}^{2} \mathrm{Kbh}: 0,589 \pm 0,142 \\
& \mathrm{~h}^{2} \mathrm{Bt}: 0,359 \pm 0,150 \\
& \mathrm{~h}^{2} \mathrm{Hb}: 0,501 \pm 0,146 \\
& \mathrm{~h}^{2} \mathrm{Bu}: 0,279 \pm 0,139
\end{aligned}
$$

Das Ergebnis ist für die Interpretation von Gestaltfaktoren bedeutsam:

1. Die Heritabilität des generellen Gestaltfaktors ist von Null signifikant verschieden. Das darf als Hinweis dafür gelten, daß es sich dabei nicht um eine ausschließlich rechnerische Größe ohne biologische Bedeutung handelt, sondern daß ihr eine gewisse genetisch fundierte Realität zugeschrieben werden darf.

2. Wäre der generelle Gestaltfaktor allein für die verschiedenen Körpermaße maßgebend, so müßte ihre Heritabilität offenbar kleiner, jedenfalls aber nicht größer als jene des Faktors sein. Ist umgekehrt die Heritabilität einzelner Maße größer als jene des Faktors, so muß man daraus schließen, daß diese Maße nicht nur vom generellen Gestalterbfaktor, sondern zusätzlich noch von anderen, spezielleren Erbfaktoren her bedingt werden. Tatsächlich weisen sowohl die Widerristhöhe wie die Kreuzbeinhöhe höhere Heritabilitäten auf als der Gestaltfaktor. Der Unterschied ist allerdings statistisch nicht gesichert.

Immerhin decken sich die Schlüsse, die man in Unkenntnis des Fehlers daraus ziehen müßte, vollständig mit jenen aus der Faktorenanalyse der genetischen Korrelationen.

Beide voneinander unabhängigen Analysen laufen also übereinstimmend darauf hinaus, daß generelle Gestalterbfaktoren zwar wahrscheinlich für einen großen Teil der Variation der Körpermaße beim Rind verantwortlich sind, daß daneben wenigstens für die Höhenmaße noch spezielle Erbfaktoren postuliert werden müssen und daß die Existenz solcher spezieller Erbfaktoren auch für andere Körperdimensionen $\mathrm{zu}$ vermuten ist.

Die Kenntnis dieser Erbfaktoren und ihrer Anteile an der Variation der Körpermaße wäre nicht nur von wissenschaftlichem, sondern auch von besonderem praktischen und züchterischen Interesse.

\section{Zusammenfassung}

1. Zwei Kriterien entscheiden über die Brauchbarkeit eines Körpermaßes: sein $\mathrm{Me} B$ feh le r und seine $\mathrm{Her}$ i t a bilit ät. Für die züchterische Auswertung bestimmt sich die Güte eines Maßes vor allem nach dem Grad seiner Erblichkeit.

2. 16 ein- und $z$ weijährige Tiere verschiedener Rassen wurden während 15 aufeinderfolgenden Wochen von je zwei Personen je zweimal unabhängig 
voneinander gemessen. Aus dem Verhältnis der $S \mathrm{treu}$ u ng k o m po$n$ e n t e $n$ für die Tiere, die Personen, die Interaktion Tier $X$ Person und den Meßfehler wurde geschlossen, daß einfache Messungen für die meisten Zwecke genügen. Sind die Tiergruppen sehr ausgeglichen, so lohnt es sich, die Messungen $\mathrm{zu}$ wiederholen, und $\mathrm{zwar}$ durch dieselbe Person, wenn personenspezifische Fehler keine Rolle spielen, und durch verschiedene Personen, wenn das Ergebnis nach außen verbindlich und vergleichbar sein soll.

3. Die photogrammetris che A us wertung von zwölf nach. einander aufgenommenen Stereophotographien desselben Tieres hat ergeben, daß der Meßfehler stark erniedrigt wird, wenn die Stellung des Kopfes und der Beine der Tiere beim Messen möglichst konstant gehalten wird.

4. In 22 verschiedenen Betrieben wurden zusätzlich gleichzeitig 175 Mutter-Tochter-Paare der Simmentaler Fleckviehrasse gemessen. Die Töchter stammten von 30 verschiedenen Stieren und waren mindestens drei Jahre alt. Aus der Intra-Vater-Mutter-Tochter-Regression wurden folgende $\mathrm{H}$ e $\mathbf{r}$ i t a bi li t ä ts we r t e bestimmt:

$\begin{array}{ll}\text { Widerristhöhe } & : 0,632 \pm 0,134 \\ \text { Kreuzbeinhöhe }: 0,589 \pm 0,142 \\ \text { Brusttiefe } & : 0,359 \pm 0,150 \\ \text { Hüftbreite } & : 0,501 \pm 0,146 \\ \text { Brustumfang } & : 0,279 \pm 0,139\end{array}$

5. Zwischen dem Durchschnitt und der Streuung der Töchtergruppen besteht eine in ihrer Tendenz positive Korrelation. Transformiert man die ursprünglichen Maße nach einer $\log$ a $\mathrm{rith}$ is che $\mathrm{Skal}$, so steigr die Heritabilität jedes Körpermaßes. Die Transformation nach einer q u a $\mathrm{d} r$ a $\mathrm{t}$ i s ch en $\mathrm{Sk}$ a 1 a erniedrigt dagegen ihre Heritabilität. Beide Effekte sind dann zu erwarten, wenn die für die Körpermaße verantwortlichen Gene nicht additiv sondern kumulativ wirken.

6. Aus den genet is chen Kor rela $t$ i on en zwischen den Körpermaßen kann geschlossen werden, daß für die Widerrist- und Kreuzbeinhöhe eine einheitliche genetische Grundlage besteht.

7. Die phänotypischen und genetischen Korrelationen zwischen den untersuchten Körpermaßen wurden einer $F$ aktorenan a lyse unterworfen. Die Heritabilität des phänotypischen generellen Gestaltfaktors beträgt 0,516 $\pm 0,156$. Dem generellen Gestaltfaktor muß somit eine gewisse genetisch fundierte Realität zugeschrieben werden, doch müssen daneben wenigstens für die Höhenmaße, vermutlich aber auch für andere Körperdimensionen Gruppenfaktoren postuliert werden.

\section{Summary}

1. The usefulness of body measurements is directly related to their e $\mathrm{r}$ r o $\mathrm{r}$ of measurement and their heritability. For breeding purposes, heritability is the more important criterion.

2. Sixteen one- and two-year old heifers of different breeds were measured twice by each of two persons during 15 consecutive weeks. C o m p o$\mathrm{nents}$ of $\mathrm{vari}$ a $\mathrm{ce}$ were determined for animals, persons, interaction animal $X$ person, and error of measurement. It was concluded that replica- 
tion of measurement is not necessary except where the groups of animals are very homogenous. In this case the measurement should be repeated by the same person where systematic errors are not of importance, and by another person where systematic errors are of importance.

3. Repeated measurements of the same cow by photogrammetric methods showed that the error of measurement can be greatly reduced, if the same position of the head and of the legs of the animal is carefully maintained each time the measurement is taken.

4. One hundred and seventy-five dam-daughter-pairs of the Simmental breed, the daughters of 30 bulls, were measured simultaneously in 22 different herds. The daughters were at least 3 years old. Intra-sire regression of daughters on dams led to the following values of he $\mathrm{r}$ it a bi lit $y$ :

$\begin{array}{lr}\text { height at withers } & : 0,632 \pm 0,134 \\ \text { height at hips } & : 0,589 \pm 0,142 \\ \text { depth of chest } & : 0,359 \pm 0,150 \\ \text { width at hips } & : 0,501 \pm 0,146 \\ \text { circumference of chest }: 0,279 \pm 0,139\end{array}$

5. A positive correlation exists between the means and the variances of the groups of daughters. The transformation of the original values on a $\mathrm{log}$ a $\mathrm{rith} \mathrm{m}$ ic s c a le results in an increase of heritability of each measurement. The transformation to a $\mathrm{quadr}$ a tic scale decreases the heritability. Both effects are to be expected if the genes for body size act cumulatively instead of additively.

6. From the genetic correlations between the body measurements it was concluded that height at withers and height at hips are connected by the same genetic factors.

7. The phenotypic and genetic correlations between the body measurements were subjected to a f a ctor an alysis. The heritability of the general phenotypic size factor amounted to $0,516 \pm 0,156$. Therefore, the general phenotypic size factor is of a concrete, genetically determined nature. In addition to this fact, however, group factors have to be postulated, at least for the measurements of height and probably for other body dimensions too.

Meinem verehrten Lehrer, Herrn Prof. Dr. H. Lört'Scher, möchte ich für die Förderung dieser Arbeit, die auf seine Veranlassung durchgeführt wurde, aufrichtig danken.

Die Stereoaufnahmen wurden im photogrammetrischen Institut der E.T.H. ausgewertet. Dem Leiter dieses Institutes, Herrn Prof. Dr. W. Zeller, und seinen Assistenten danke ich für ihre wertvolle Hilfe. Herrn dipl. ing. agr. H. Eugster, Assistent am Versuchsgut für Tierzucht Chamau, möchte ich für seine Mitwirkung bei den Tiermessungen und Herrn dipl. ing. agr. Dr. H. L. LE Roy, Assistent am Institut für Tierzucht der E.T.H., für seine Ratschläge bei der statistischen Auswertung herzlich danken.

Herr Dr. E. JenNi, der Leiter der Herdebuchstelle für Simmentaler Fleckvieh, war bei der Auswahl der Tiere für die Heritabilitätsuntersuchung behilflich. Ihm und allen Tierbesitzern, die uns die Durchführung der Messungen ermöglichten und erleichterten, sei besonders gedankt. 